\title{
Origin and Circulation of Calcarenite Artifacts in the Area of Montescaglioso between 6th and 3rd Century BC: An Interdisciplinary Approach
}

\author{
Dimitris Roubis ${ }^{1, *}$ and Claudia Sciuto ${ }^{2}$ \\ 1 Graduate School in Archaeology, Matera-University of Basilicata, IBAM-CNR, 75100 Matera, Italy \\ 2 MAL-Environmental Archaeology Laboratory, University of Umeå, 90187 Umeå, Sweden; \\ claudia.sciuto@umu.se \\ * Correspondence: d.roubis@ibam.cnr.it
}

Received: 13 December 2018; Accepted: 23 January 2019; Published: 31 January 2019

\begin{abstract}
The study of stone artifacts and their provenance is an important proxy for understanding the entangled relationship between humans and geological resources. In this paper, we explore the potentialities of an interdisciplinary approach combining in situ documentation of tool marks and characterization of stone types using a near infrared (NIR) portable probe. We argue that this protocol is useful for collecting screening data on objects that cannot be moved or sampled. NIR spectra describe textural and molecular features of the materials and can be used to achieve a preliminary characterization of raw materials. We present a case study from the territory of Montescaglioso (Basilicata, near Matera, Italy), where we combined the analysis of a calcarenite (limestone) quarry, in Masseria D'Alessio, which was exploited since the 6th century BC, as well as artifacts of the same chronology from surveys and excavations in the surroundings. The aim was to collect preliminary data about the distribution of the particular calcarenite extracted from the quarry and identify exploitation and trade patterns. The data were processed using multivariate statistics to highlight the relevant spectral information and perform supervised classification of spectral features. Documentation of tool marks and the process of stone working were combined with the spectral signature of the artifacts to link the stone types to the description of their extraction/carving methods.
\end{abstract}

Keywords: stone coffins; limestone; multivariate statistics; near infrared spectroscopy; quarry

\section{Introduction}

In the territory of Montescaglioso, an intensive archaeological survey focused on the reconstruction of ancient landscapes in the lower valley of river Bradano, near the Ionian coast of Basilicata (South Italy). Thanks to the archaeological survey, it was possible to document a great number of sites, mostly dated to Classical and Hellenistic periods [1]. The research presented is part of a wider program of intensive archaeological field survey, as part of a project of landscape archaeology in the entire area of Montescaglioso. The project has been conducted since 2007 by the Graduate school in Archaeology of Matera (SSBA-UNIBAS) in collaboration with the Soprintendenza Archeologia, Belle Arti e Paesaggio della Basilicata (SBA-BAS) and the Italian Research Council (IBAM-CNR) [1-7]. The purpose of this project is to provide important data for archaeological settlement reconstruction and discovering how the landscape, the geographical, and the territorial parameters influenced the exploitation of a territory and the development of settlements in the study area. For this reason, since the beginning of the survey project, an interdisciplinary approach was used, which provides a wide range of articulated methods and techniques. One of these is aimed to localize possible origin areas of lithic materials, which are related to production activities of the past. 
The characterization of raw materials and supply sources during the survey implies the application in situ of an interdisciplinary protocol of documentation and geochemical analysis of stone artifacts. The objects' shape and context can be registered through GPS and 3D modeling (from photogrammetry), combined with an attentive observation and documentation of tool marks. On the other hand, geological information about rock composition can be achieved through chemical characterization of the artifacts. Portable analytical instruments can be used during surveys in order to avoid invasive sampling on objects that cannot be moved. Several methods are currently available and relatively small probes that can be transported such as portable X-ray fluorescence-XRF-or Raman spectrometers. These techniques are useful for classifying some particular elements but have scarce sensitivity toward trace elements, while the inbuilt calibration system could cause issues and biases for quantification [8-11]. In this study, an exploratory characterization of stone types is carried out by using a portable near infrared (NIR) spectrometer in order to collect fingerprint data [12].

The area of Montescaglioso (Basilicata) is a pilot case study because of its particular settlement and geographic features. In this territory, during the project of extensive survey and documentation of surface archaeological evidence, several artifacts made of calcarenite (sand-size grained limestone) have been documented in different indigenous sites [1,4,13-16]. The focus of the inquiry was on outlining the dynamics of production and trade of calcarenite artifacts during the period from the 6th to the 3rd century BC.

\subsection{The Historical and Archaeological Context}

The site of Montescaglioso is one of the largest indigenous settlements in the area, framed mainly between the Arcaic Age and the late Hellenistic period (8th-1st century BC). The site is situated on the highest point of a hill system bordered by the river Bradano and its tributary, the Gravina-Fiumicello stream. At the farthest spurs of the hills and terraces around the Montescaglioso upland system, the distribution of the ancient human settlement, near the river Bradano, is characterized by the presence of important villages of the Classical period, known by their modern names of Difesa San Biagio and Pagliarone (Figure 1).

The area object of the study is located in a strategic position, controlling the confluence of the rivers Bradano and Gravina-Fiumicello, which are closed to the norther border of the territory pertinence of the Greek colony of Metaponto (chora of Metaponto). This colony was founded in the 7th centuries BC by colons from the Achaean region (Peloponnese) [17-20]. The indigenous population living in Montescaglioso was in contact with the Greeks through a dense network of trades and exchanges, as documented by the material cultural evidence. During the 90s, some excavations were carried out on the sites of Difesa San Biagio, Pagliarone (situated south-east of Difesa San Biagio) and Montescaglioso [4,5,13-15,17,21-23]. The archaeological record showed evidence of huts and rectangular dwellings dating back to the Iron Age (8th century BC) and occupied until the 1st century $\mathrm{BC}$, with a later partial abandonment of the settled areas up until the 11th century, when the Benedictine monastery of S. Michele Arcangelo was founded on the top of the hill of Montescaglioso. The data collected during the survey reveal a more complex scenario, with an intricate network of archaeological sites of various chronologies distributed both along the course of the rivers and on the higher ridges of the hills. During several survey campaigns, evidence of settlements, farms, and several production sites have been documented, which delineated a complex system of communities, raw materials exploitation, manufacture, and exchanges [1]. In the surveyed territories, several stone artifacts related to the ancient settlements, such as walls, coffins, and millstones, have been identified. These objects seem to be produced using the local calcarenite, which is soft, easy to work with, and quite resistant. 


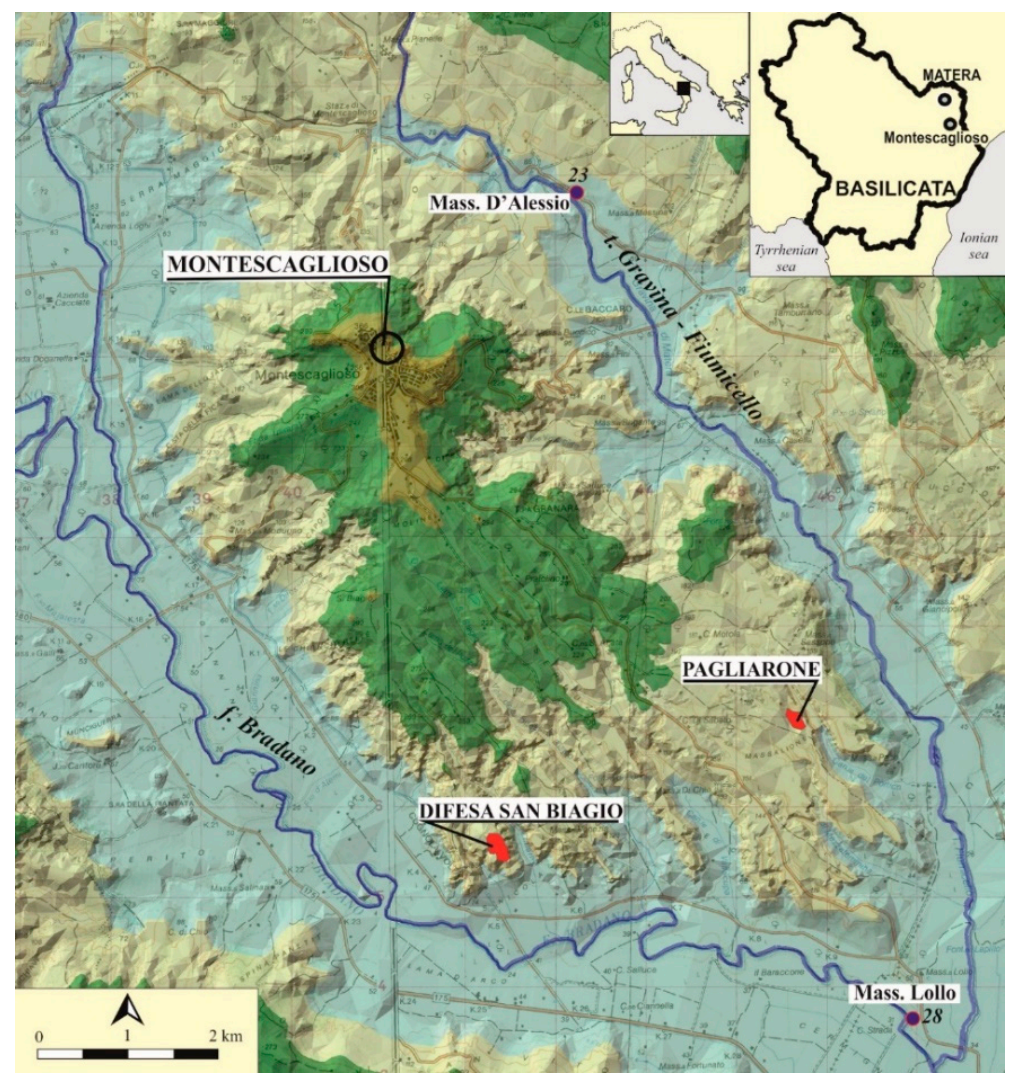

Figure 1. The study area is situated between the Bradano and Gravina-Fiumicello rivers, close to the eastern border of Basilicata, in Southern Italy. The image above shows the valleys of Bradano and the Gravina-Fiumicello. In the center is the area of Montescaglioso, the settlements of Difesa San Biagio and Masseria Lollo in an elevated position, in order to control the Bradano valley. The quarry site identified at Masseria D'Alessio is located by the Gravina-Fiumicello stream [3].

The objects were analyzed directly in the field applying an experimental protocol combining the analysis of the geochemical signature of limestone types and the study of the stone carving process. Measurements performed with the portable NIR were associated with detailed documentation of morphologies through photogrammetry. The measurements were carried out in two separate campaigns, during the fall of 2015 and the spring of 2018, and allowed the collection of data about the provenance (on the difference between provenance and provenience, see [24]) of the objects, the organization of labor, and economic exchanges in the area.

\subsection{The Study Area}

The area of Montescaglioso is enclosed between the iconic landscape of Matera with its limestone canyons, and the costal plane of Metaponto with alluvial deposits and dunes. A thick layer of marly clay constitutes the hill, on which the town is situated. The deposits, dated to the Pliocene, are covered by relicts of Pleistocene alluvial terraces originated by sediments from the river Bradano. These formations are located on a hill slope and, therefore, subject to landslides [25,26]. In a landscape dominated by smooth, low hills, an abrupt exception is the limestone cliff longing the upper river of the Gravina-Fiumicello. In this area (upper right in Figure 1), a long outcrop marks the southern extremity of the Gravina calcarenite formations, white-yellow limestone constituted of carbonate sand-size grains, and characterized by the presence of conglomerate layers at the base of the sequence. In the area between Montescaglioso and Matera, the calcarenite fomations are more frequent and cover the white limestone of Altamura, dated to the Cretaceous [27]. 
Along the left bank of the Fiumicello stream, it was possible to locate some archaeological evidences of extraction activities dated to the Arcaic and Classical period (6th, but mainly, 4th and 3rd century BC). Several calcareous banks, belonging to the last offshoots of the lithological formation of the Murgia plateau of Matera, are exploited as latomie [27]. The area, in which clear traces of this type of specialized activity have been documented (quarry shelves on a front of about $130 \mathrm{~m}$ ) and dated to the Classical period, has been identified opposite the Masseria D'Alessio (site $23=$ UT 37). The hypothesis is that this part of the quarry provided stone elements for funeral use (sarcophagi) and for other types of artefacts. Artefacts with analogous lithological characteristics were found in various burial sites in the district (like the classical farm site of Masseria Lollo: site $28=$ UT 43), as well as in the excavated houses and necropolis of the Classical village of Difesa San Biagio and in the fortification walls of Montescaglioso (via Porta Schiavone).

\subsubsection{Masseria D’Alessio (Site 23)}

Along the Gravina-Fiumicello River, in proximity to the Provinciale Messapica road, it was documented as an outcrop featuring traces of ancient quarrying activities [1]. The cliff is approximately 130 meters in length and appears to have been carved in a calcarenite formation.

Sites of this type are quite rare and are often destroyed by subsequent extraction activities, since they are located in proximity to suitable stone outcrops. The systematic study of ancient quarries is of great importance for understanding production mechanisms and the organization of labor. Observations of the morphology of the quarry face permitted the identification of different tool marks. Such traces are fundamental to understanding what kind of tools were used by quarrymen, as well as the organization of various stages of extraction and carving of blocks. Several quarrying strategies can be identified by studying the tool marks [28-31]. In the case of Masseria D'Alessio, the first segment of the quarry wall visible from the southeast shows traces of ancient activity. Our inquiry focused on this portion in order to document a phase of exploitation of the quarry which, according to the surface found collected in this area, probably dates back to the 6th century, with the main phase of use by the 4 th-3rd century BC $[3,6]$. The quarry face has an irregular profile due to the prolonged use over time. Few blocks of rough stone have been laid along the course of the river, which is a probable indication of a landing place for boats destined to transport the materials.

\subsubsection{Difesa San Biagio}

The indigenous settlement of Difesa San Biagio has been the object of various investigations [5,15-17,32]. The site covers a surface of 4 ha and is located on upland, in a strategic position in order to control the Bradano River, surrounded by cliffs and accessible only from a narrow trail. A large area occupied by structures interpreted as dwellings was mapped through intensive surveys, geophysical mapping, and excavations. The site was inhabited from the Late Bronze Age to the Late Roman Republican period. During the excavation, a large millstone dated to the Hellenistic period, likely used as an olive press, was found and is still visible in-situ. This find is particularly interesting considering that oil production was an important activity in the neighbouring chora of Metaponto and the presence of an oil press in the settlement of Difesa San Biagio could be a result of trading and contact between the two areas. During the excavation, a calcarenite mortar, used as a food grinder, was also found. To the northeast of the dwelling structure, a big necropolis area was excavated in the beginning of the 1990s. Calcarenite coffins found during the excavation consist of two parts: a rectangular tub and a covering slab (Figure 2). Some of the coffins have sustained damage, with broken and missing parts. 


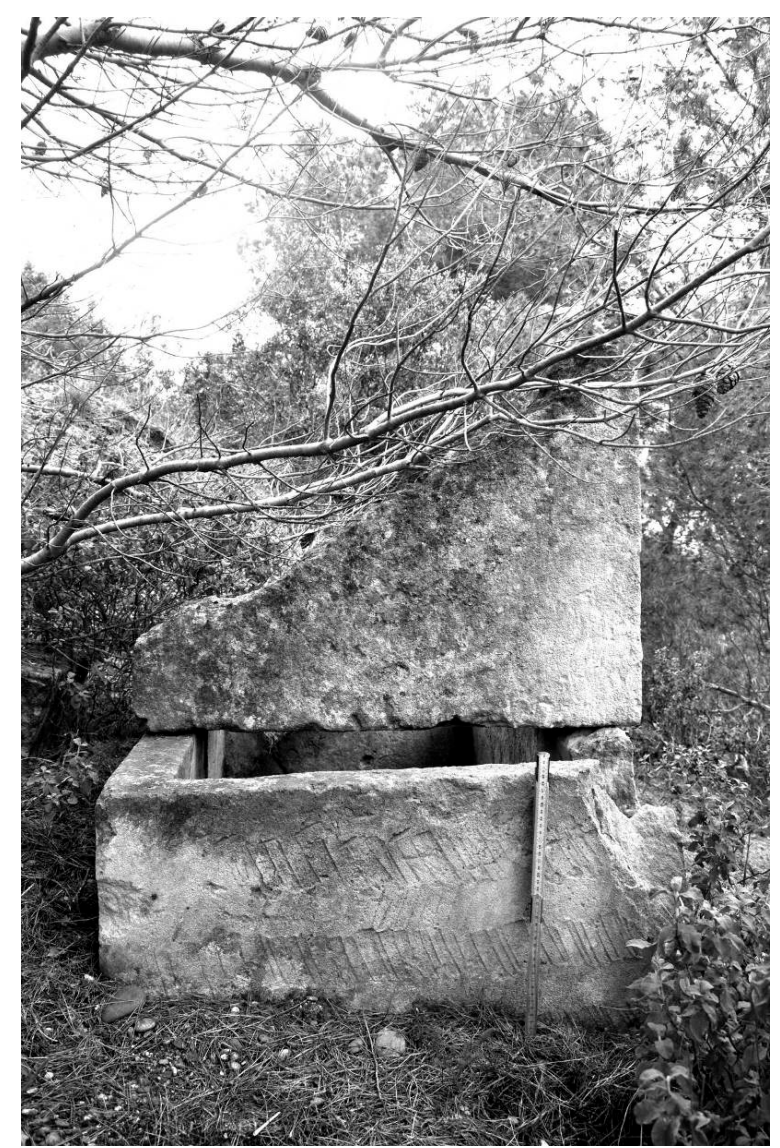

Figure 2. Coffin T96 with covering slab (broken), from the necropolis of Difesa San Biagio.

\subsubsection{Masseria Lollo (Site 28)}

In the location called Masseria Lollo, the survey documented a high dispersion of surface materials including the remains of seven coffin-covering slabs (Figure 4). The site is located on a low promontory at the confluence of the two rivers (Figure 1). The settlement has been interpreted as a farm dated to the 4th-3rd century BC with an adjacent sepulchral nucleus. The calcarenite slabs were found at ground level, out of context, likely piled there in order to clean crops for modern agricultural activities. The site has not been excavated and the available information has only been deduced from the survey data.

\subsubsection{Montescaglioso (via Porta Schiavone)}

Several investigations have been carried in the village of Montescaglioso [13,14,21-23,33]. The origin of the indigenous settlement on top of the hill dates from the Late Bronze Age to the Late Roman Republican period, marked by a significant population growth between the 7th and 4th century BC. During an excavation in 1992 (via Porta Schiavone), the fortification wall was discovered and dated to the late 4th century BC [13]. The wall reveals two perpendicular portions, which are comprised of dressed elements in calcarenite [14]. The structure is situated close to an access path to the promontory top and presents a peculiar plan (perpendicular walls) that appears to have been built by adapting to the natural morphology of the slope, which takes advantage of the natural configuration of the hill for defensive purposes [23]. The wall encloses a terrace with few burials and several walls interpreted as dwellings dated to the 4th century. 


\section{Materials and Methods}

Documentation of evidence and analytical measures were carried out in the mentioned sites. Analytical measurements in Masseria D'Alessio, on the quarry face, were repeated in 2015 and 2018 in order to have a more reliable dataset for classification. In Difesa San Biagio, 14 coffin tubs, 20 covering slabs, the millstone, and the mortar were included in the dataset analyzed during the campaign in 2015. In Masseria Lollo, seven covering slabs were analyzed during the 2015 campaign, while, in Montescaglioso in 2018, the study included the defensive walls together with a small coffin and covering slab.

Each artifact has been analyzed in the field following a protocol that involves different integrated methods. The location of every object is recorded via GPS (Geographic Positioning System) and is referred to the existing project documentation. Context, volume, and shape are documented in 3D through SfM (Structure from Motion), while the surface of the rock is chemically characterized using a portable near infrared probe collecting several point recordings.

\subsection{Tool Marks}

Particular attention was given to the items' surface in order to spot traces of tools used for carving and dressing the stones. The identification of manufacturing tools and their specific use from the marks left on the materials is a technique that permits the definition of the various stages of the production chain quantifying methods and times of labour [28-31]. This approach to rock sites, which is widely applied to the study of quarry areas or rock-cut settlements, supports the definition of a relative chronology of carved/dressed surfaces together with the description of the technique used, based on ethnographic or experimental comparisons. For each object analyzed, the traces of tools are recorded reporting the direction and trend. The thickness and depth of the carvings are measured as well as the interval between consecutive traces.

\subsection{Near-Infrared Spectroscopy}

Accurate geological and chemical analysis on stone artefacts are usually carried out in laboratory, with procedures frequently time consuming, expensive, and requiring the collection of various samples (i.e., petrographic analysis, $\mathrm{X}$-ray fluorescence spectrometry, inductively coupled plasma mass spectrometry, and neutron activation analysis [34-36]). This approach can provide archaeologists with very accurate analytical data but must be limited to few selected items. Considering this sampling issue, an intermediate stage in the characterization of materials was achieved by using, during the survey, a portable near infrared probe. NIR spectroscopy is based on recording the molecular absorption of light emitted from a controlled source on a series of wavelengths. NIR spectroscopy is a non-invasive technique widely used in geology and archaeology for remote sensing analysis. This method allows the collection of a large number of measurements in a very short time and is, therefore, suitable for screening of big quantities of materials. By multiplying the number of measurements, we can collect datasets that are representative of the geological variability on the materials' surface. This versatile technique is used at different scales, for reading satellite images, creating terrestrial geological maps, analyzing the lunar surface, and for mining explorations [37-40]. In archaeology, infrared spectroscopy has been widely used for surveys of aerial or satellite images [41,42] and provenance studies [24,43-48]. All infrared spectra contain diverse information that refers to the various properties of the materials. Each recording includes spectral features resulting from the color of the material and its texture as well as vibration of molecules in the first, second, and third overtone regions. Near infrared spectroscopy does not deliver quantitative information about the composition of a particular stone but each infrared spectrum constitutes a unique fingerprint of the material. NIR portable probes can be used for collecting data on geological artifacts in situ, the datasets grant a good representation of molecular features and can be considered a preliminary step in the identification of raw material supply sources (see the detailed comparison and combination of NIR and XRF [47]). 
The instrument used in this study is Micro NIR, which is a portable spectrometer produced by VIAVI that can be connected to a computer or tablet via USB. The probe has a diameter of $42 \mathrm{~mm}$ and it can be held in one hand. The sensor comprises two integrated vacuum tungsten lamps that illuminate the sample and a central captor (128 pixel Array InGaAs elements). The field of view for recording spectral information is a rectangle of around $4 \times 5 \mathrm{~mm}$. The recorded spectra extend from 950 to $1650 \mathrm{~nm}$, with a $6.2 \mathrm{~nm}$ interval between bands. The spectrometer is calibrated with reference measurements at $0 \%$ and $100 \%$ absorption (100\% on white Spectralon and $0 \%$ on black sandpaper). The integration time for measurements is $10 \mathrm{~ms}$ and it weighs 64 grams, which makes it a light and fast device, easily transported in a backpack. The software used for data acquisition and management is MicroNIR Pro ES 1700, installed on a tablet. Sampling strategy is usually calibrated on the target. Quarry walls are sampled through consecutive measurements aligned in series, in order to register the eventual variability of the geological formation. The measurements of single objects (at least three measurements per item) are carried out in random positions, which avoids weathered surfaces and biological alterations. For each object, the exact position of the measurements is recorded and annotated directly on a photo taken with the tablet.

Spectral data of all solid substances are influenced by an optical scattering effect that could create background noise and obliterate some information. In order to pre-process the data, increase the spectral differences and reduce the signal disturbance. Various correction techniques can be applied such as the Standard Normal Variate (SNV) or scaling algorithms including mean centring [49].

The collection of extended datasets allows a detailed visualization of the chemical variability of the objects, although the analysis of large volumes of data must be performed through multivariate statistics such as cluster analysis and classification algorithms. Spectroscopic data are recorded as a data matrix on a spreadsheet (comma separated) containing a number of variables equal to the recorded bands (128 in the case of the JDSU MicroNIR portable spectrometer). Spectral information, clustering, and patterns can be highlighted by applying a data-driven approach derived from chemometrics based on multivariate statistical modelling [50-52].

\section{Results}

\subsection{Masseria D'Alessio}

The part of the quarry face analyzed in detail is around 9 meters in length, for $3 / 3.5$ meters high. The extraction strategy was organized on ledges with a variable thickness. An extraction module was identified at the base of the vertical wall, which is likely relevant to the latest phase of exploitation. Tool marks define the shape of the extracted elements, quarried on overlapping banks with variable heights from 45 to $60 \mathrm{~cm}$. Between levels, traces of the extraction furrows made it possible to measure the dimensions of the tool blades used by quarrymen. The identified traces refer to tools that function through direct percussion (or launched), used for carving the lateral furrows, and to even out the quarry profile. The cutting direction is often crossed, from right to left and from left to right (Figure 3). The measurements of the blade profile vary from $2.5 \mathrm{~cm}$ to $4 \mathrm{~cm}$ in width. Traces in this sector are redolent of an extraction strategy that is quite well known and common to limestone quarries. Workers would use pickaxes to carve lateral furrows around the block and isolate the lower face that would be subsequently detached with the help of wedges. At least two different types of pickaxe have been identified: one with a $4 \mathrm{~cm}$ wide blade that has been used to extract the regular $45 \mathrm{~cm}$ thick blocks in level 10, and another pickaxe with a $2.5 \mathrm{~cm}$ wide blade used for all the rest of the exploitation. Measurements with the portable probe were carried out both in 2015 and in 2018 by sampling the rock face vertically, in various profiles. 


\begin{tabular}{|c|c|}
\hline \multicolumn{2}{|c|}{ Legend } \\
\hline $\mathbb{I} U$ & pickaxe blade mark \\
\hline $1 \ll$ & pickaxe point mark \\
\hline- & traces of extracted blocks \\
\hline$\%$ & ground soil \\
\hline$\ldots$ & excavation limit \\
\hline$\ldots$ & non visible \\
\hline .12 & MicroNIR measurement reference \\
\hline
\end{tabular}

\section{Quarry face, Masseria D'Alessio}
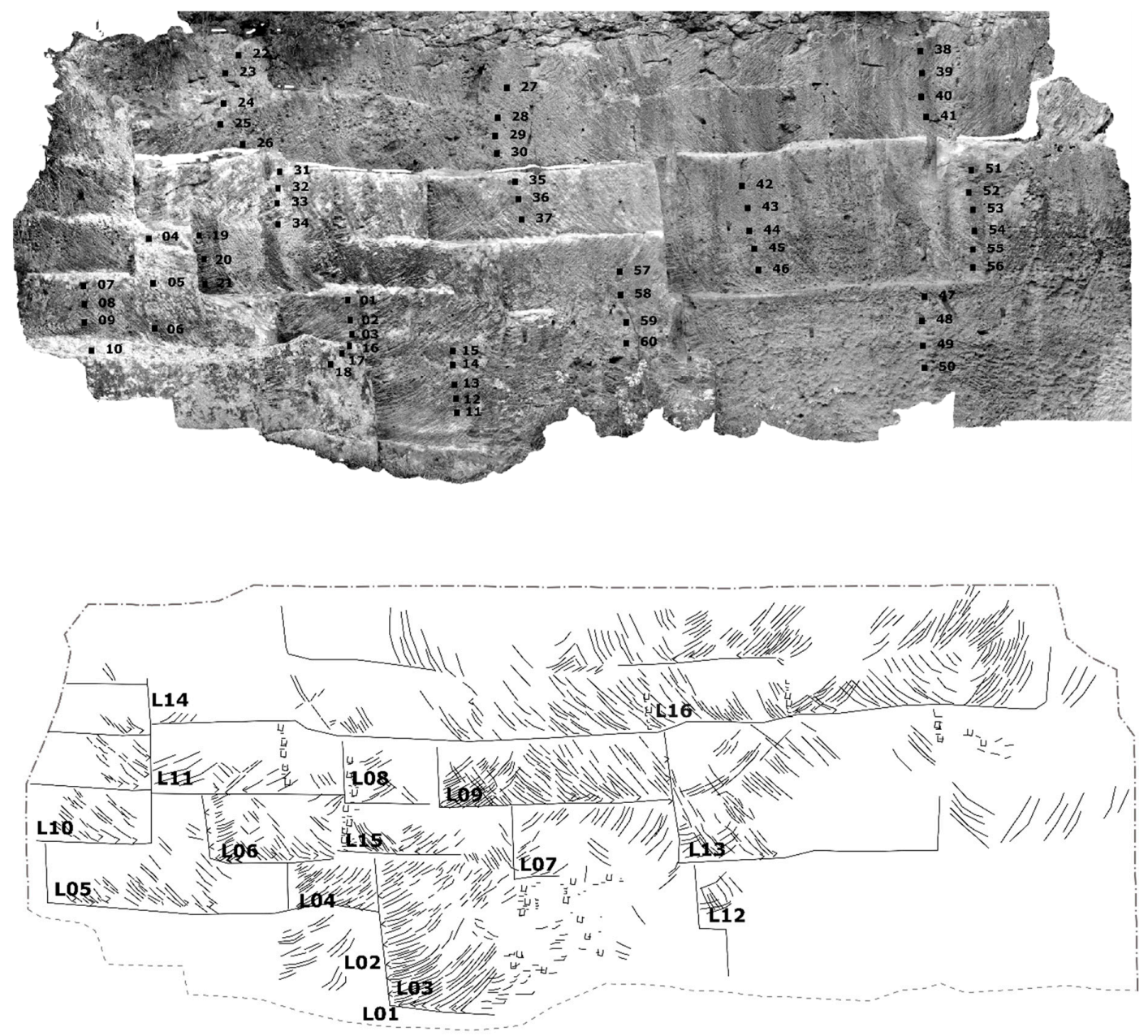

$1 \mathrm{~m}$

Figure 3. Documentation of the quarry face at Masseria D'Alessio.

In Figure 3, the ortho-photo of the quarry face is shown with an outline of tool marks, overlapping extraction shelves numbered in sequence, and position of NIR measurements. In Table 1, the measures of the extracted blocks are listed according to the numbering in Figure 3. 
Table 1. Measures of the blocks extracted from the quarry wall in Masseria D'Alessio. The numbering refers to Figure 3.

\begin{tabular}{ccccc}
\hline Level & Height $(\mathbf{c m})$ & Length $(\mathbf{c m})$ & Large $(\mathbf{c m})$ & Tool Blade \\
\hline L1 & & 60 & & 2.5 \\
L2 & & & & \\
L3 & 45 & 110 & $60(?)$ & 2.5 \\
L4 & 60 & 45 & & 2.5 \\
L5 & 55 & 190 & \\
L6 & 55 & & \\
L7 & 45 & & \\
L8 & 55 & & \\
L9 & 55 & $95-190$ & \\
L10 & 45 & 130 & \\
L11 & $45 / 50$ & 130 & \\
L12 & & & \\
L13 & $45-90$ & 190 & \\
L14 & 55 & & & \\
L15 & 45 & & & \\
L16 & 45 & & & \\
\hline
\end{tabular}

\subsection{Difesa San Biagio}

In Difesa San Biagio, the detection of tool marks and measurement of sarcophagi and associated cover slabs has been made difficult, sometimes impossible, by the artifacts' state of conservation. The coffins' surface was altered by atmospheric events with many fractures and missing parts. Nevertheless, NIR analyses were carried out taking care to sample the un-weathered portions, while documenting the shape of intact artifacts. The coffins present irregular dimensions with a length variable between 80 and $100 \mathrm{~cm}$. The effects of weathering on the rock surface affected the visibility of tool marks. Nevertheless, the coffins' surface appears to be polished, with a decorative pattern carved on the side. The visible traces are around $10 \mathrm{~cm}$ long and $0.5 \mathrm{~cm}$ wide, arranged diagonally on superposed bands and probably obtained using a chisel or a flat axe (Figure 2). For each object, at least three points were measured using the NIR probe.

The information collected is summarized in the following table (Table 2). The burial number (from the excavation) identifies each coffin and it indicated if the measurements refer to the slab (l) or the tub(s).

Table 2. Dimensions of coffins and covering slabs from the site of Difesa San Biagio.

\begin{tabular}{cccc}
\hline Object & Height $(\mathbf{c m})$ & Length $(\mathbf{c m})$ & Large $(\mathbf{c m})$ \\
\hline T056_1 & 22 & 146 & 90 \\
T056_s & & & \\
T057_1 & 30 & & 100 \\
T058_1 & 16 & 140 & \\
T058_s & 78 & & \\
T059_1 & 20 & 140 & \\
T059_s & & 143 & 80 \\
T061_1 & 22 & 120 & \\
T061_s & & 140 & 80 \\
T069_1 & 17 & & \\
T070_1 & 25 & & \\
T074_s & & & \\
T075_1 & 24 & & \\
T075_s & & & \\
\hline
\end{tabular}


Table 2. Cont.

\begin{tabular}{cccc}
\hline Object & Height $\mathbf{( c m )}$ & Length $\mathbf{( c m )}$ & Large $(\mathbf{c m})$ \\
\hline T076_1 & 30 & & 90 \\
T076_s & & 140 & 82 \\
T096_1 & 20 & & \\
T096_s & & & 80 \\
T097_1 & 20 & & \\
T100_1 & & & 95 \\
T100_s & & $70(\times 2)$ & \\
T102_1 & 32 & $67(\times 2)$ & 80 \\
T102_s & & $70(\times 2)$ & 94 \\
T105_1 & 20 & 130 & 90 \\
T105_s & & & 85 \\
T109_1 & 30 & 120 & 74 \\
T112_1 & 30 & $72(\times 2)$ & 90 \\
T112_s & & & \\
T113_1 & 12 & $70(\times 2)$ & 85 \\
T113_s & 73 & & \\
T118_1 & 25 & & \\
T118_s & & & \\
T141_1 & 27 & & \\
T141_s & & & \\
T144_1 & & & \\
\hline
\end{tabular}

\subsection{Masseria Lollo}

The seven coffin-covering slabs identified at the site of Masseria Lollo presented very weathered surfaces with ongoing biological activity (mosses and lichens). Because of the alteration, collecting measurements was quite problematic. The slabs are about $1 \mathrm{~m}$ long with a very variable width and are around 40 to $50 \mathrm{~cm}$ thick. It is impossible to determine if these blocks were part of one or more burials, but the shape recalls typologies of coffins common in this area between the 6th and 4th century BC. Manufacturing details, when visible, are reminiscent of the production of the coffins observed in Difesa San Biagio. The surface appears to be polished and there are no signs of decorative patterns on the covering slabs, with barely visible traces of a stonemason's pick used on the side (Figure 4). Each item has been analyzed using the NIR spectrometer, taking care to avoid the altered surface.

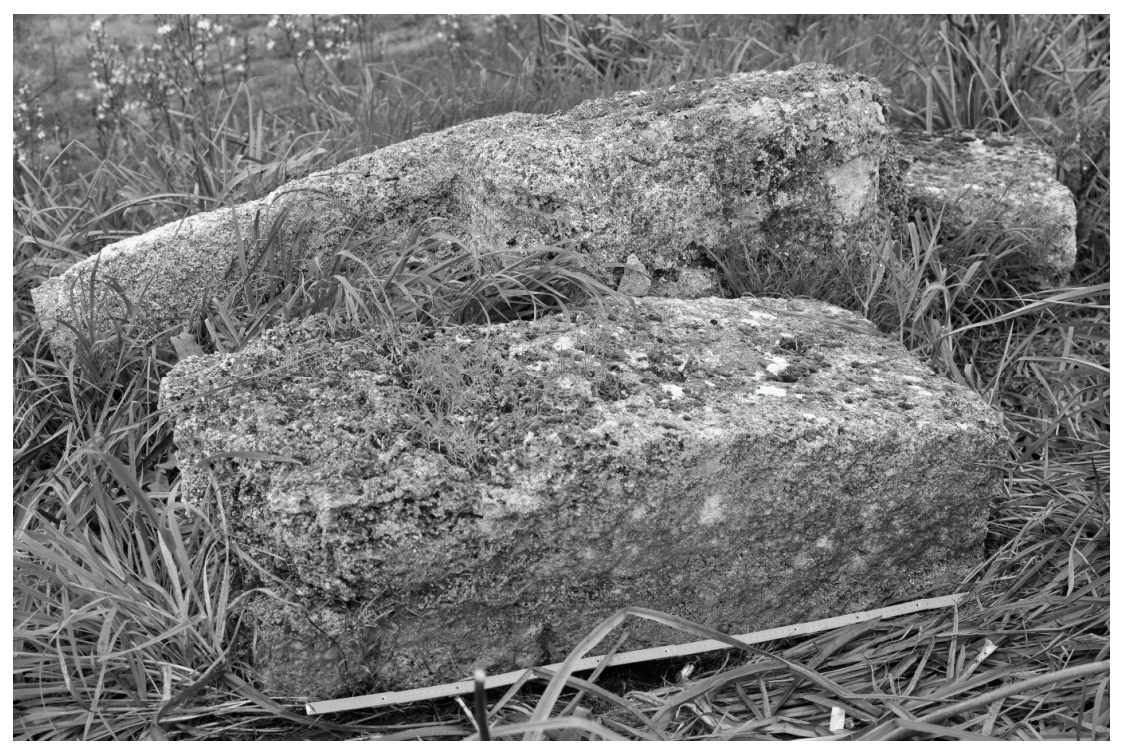

Figure 4. Coffin covering slabs discovered at the location named Masseria Lollo. 


\subsection{Montescaglioso, via Porta Schiavone Fortification Walls}

The archaeological area of via Porta Schiavone displays distinct results of dwellings. Among the various structures, calcarenite artifacts are less abundant than objects made from the local conglomerate. NIR measurements were performed on a small coffin (Figure 5) and on two perpendicular portions of the defensive walls. The small coffin measures about $30 \times 50 \times 80 \mathrm{~cm}$, is carved from one block of calcarenite and, on the external face, displays traces of a flat chisel used for evening out the rock. The internal surface shows the marks of a hand chisel. The defensive walls are built using regularly dressed calcarenite blocks with dimensions of around $85 \times 42 \times 42 \mathrm{~cm} \mathrm{[14].} \mathrm{The} \mathrm{tool} \mathrm{marks} \mathrm{show}$ that stone modules on the uppermost row were dressed as handling tools different from those used for the modules below. This different treatment is likely due to the function of the lower bedding. Stratigraphic data from the excavation have highlighted that the blocks that are currently visible from part of the wall's foundation. These lower beddings are lined up with elements that appear rougher, without a polished surface, dressed using a pickaxe. The first stage of the stone-cutting process was probably carried out directly at the quarry and, once at the construction site, the modules were directly built into the wall. The modules that formed part of the visible portion (only the uppermost row), were evened out after positioning them on the beddings using a chisel, with a $3.5 \mathrm{~cm}$ wide blade to form an angular pattern. The surface of the masonry was redressed until reaching the ancient ground level (this is particularly visible in the NW-NE wall, upper bedding, Figure 6). The construction strategy is also expressed in some traces on the blocks: positioning notches resulting from the installation of levers to pull the blocks into their place, as well as anathyrosis marks [13] to increase the friction and adherence between the modules.

In Figure 5, part of the archaeological area of via Porta Schiavone: in the foreground, the coffin that was analyzed and one portion of the wall. In the background is the other portion. Figures 6 and 7 show ortho-photos of the walls with positions of the NIR measurements and an outline of tool marks.

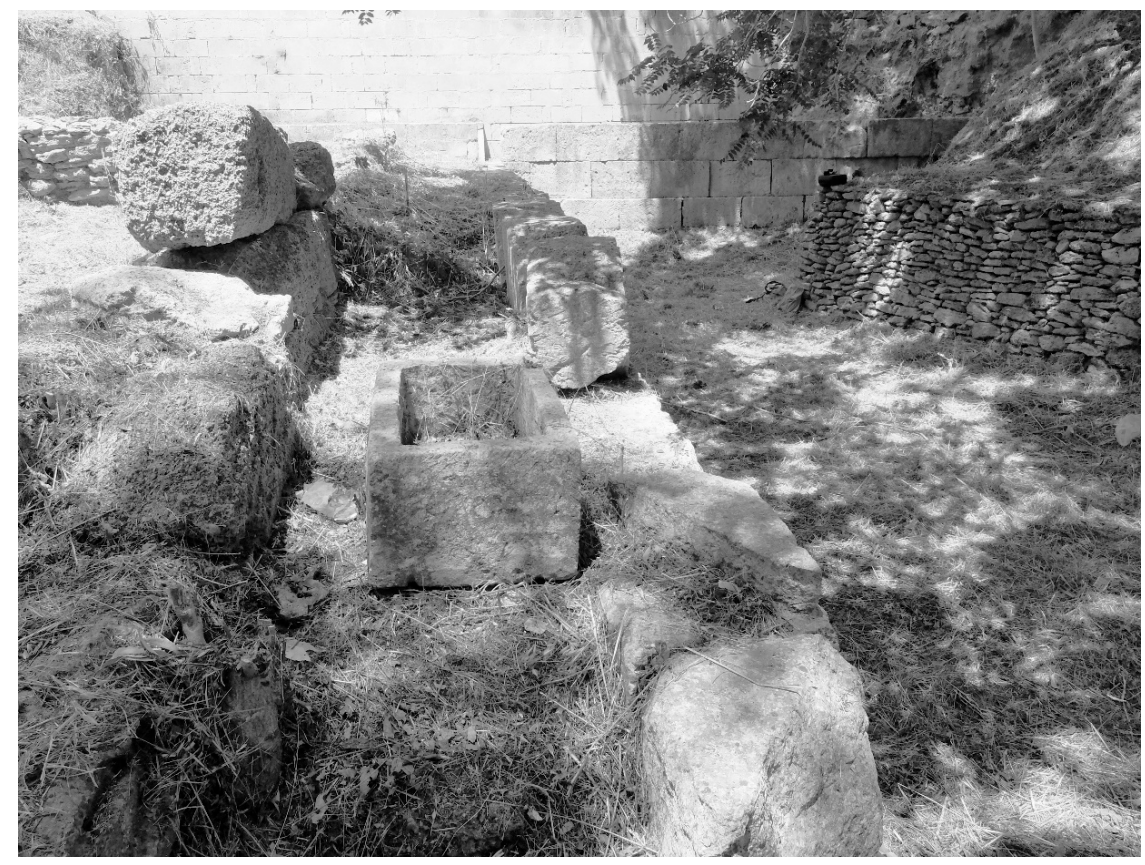

Figure 5. Porta Schiavone, Montescaglioso, archaeological area. The coffin and fortification walls that were analysed. 
Fortification wall

Montescaglioso, Porta Schiavone

NW

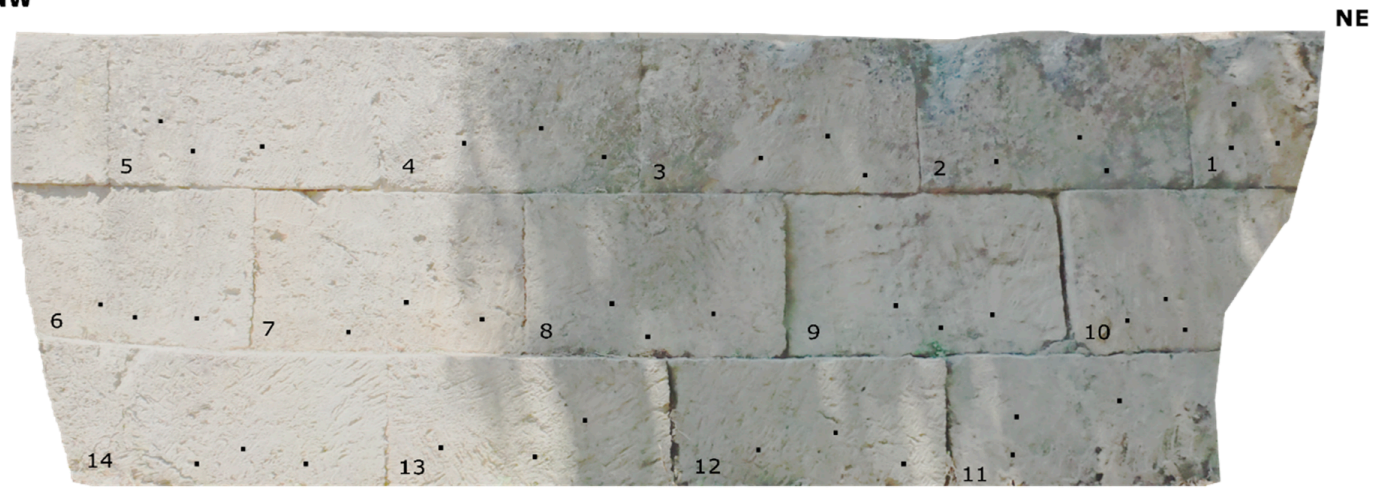

Legend

$\checkmark$ fracture

- mechanical erosion

surface gap

chiseled surface

$\checkmark \quad$ chisel blade mark

I« chisel point mark

$\nabla \quad$ positioning notch

(4). ground soil

...- excavation limit

-..- non visible

- 12 MicroNIR measurement

(12) stratigraphic unit

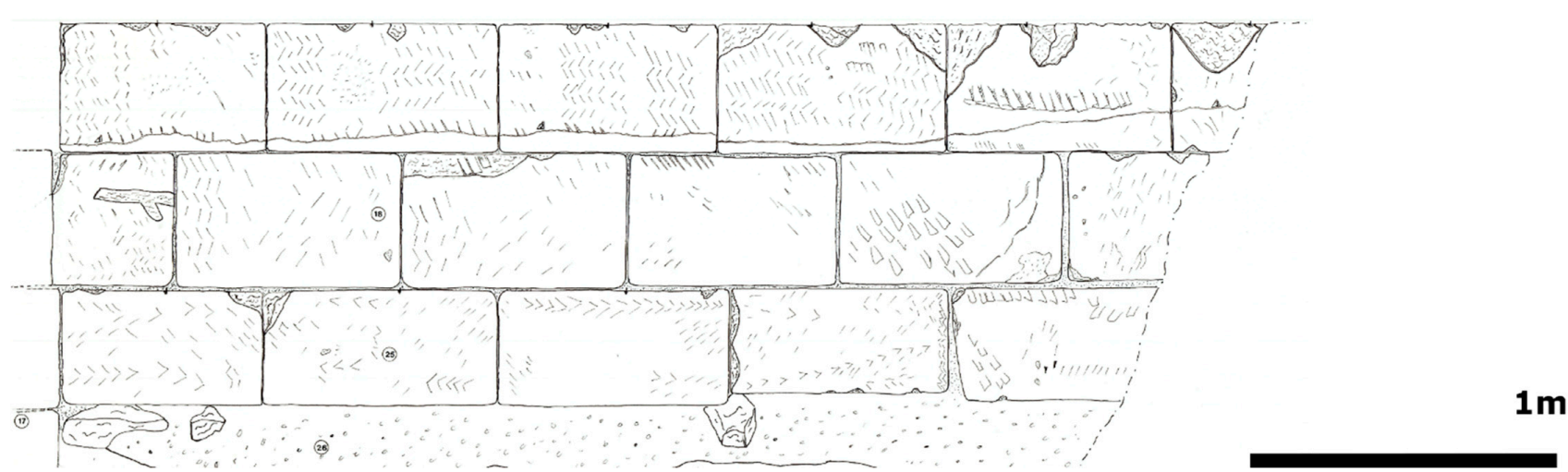

Figure 6. Documentation of one portion of the fortification wall at the site of Porta Schiavone, Montescaglioso [24]. 


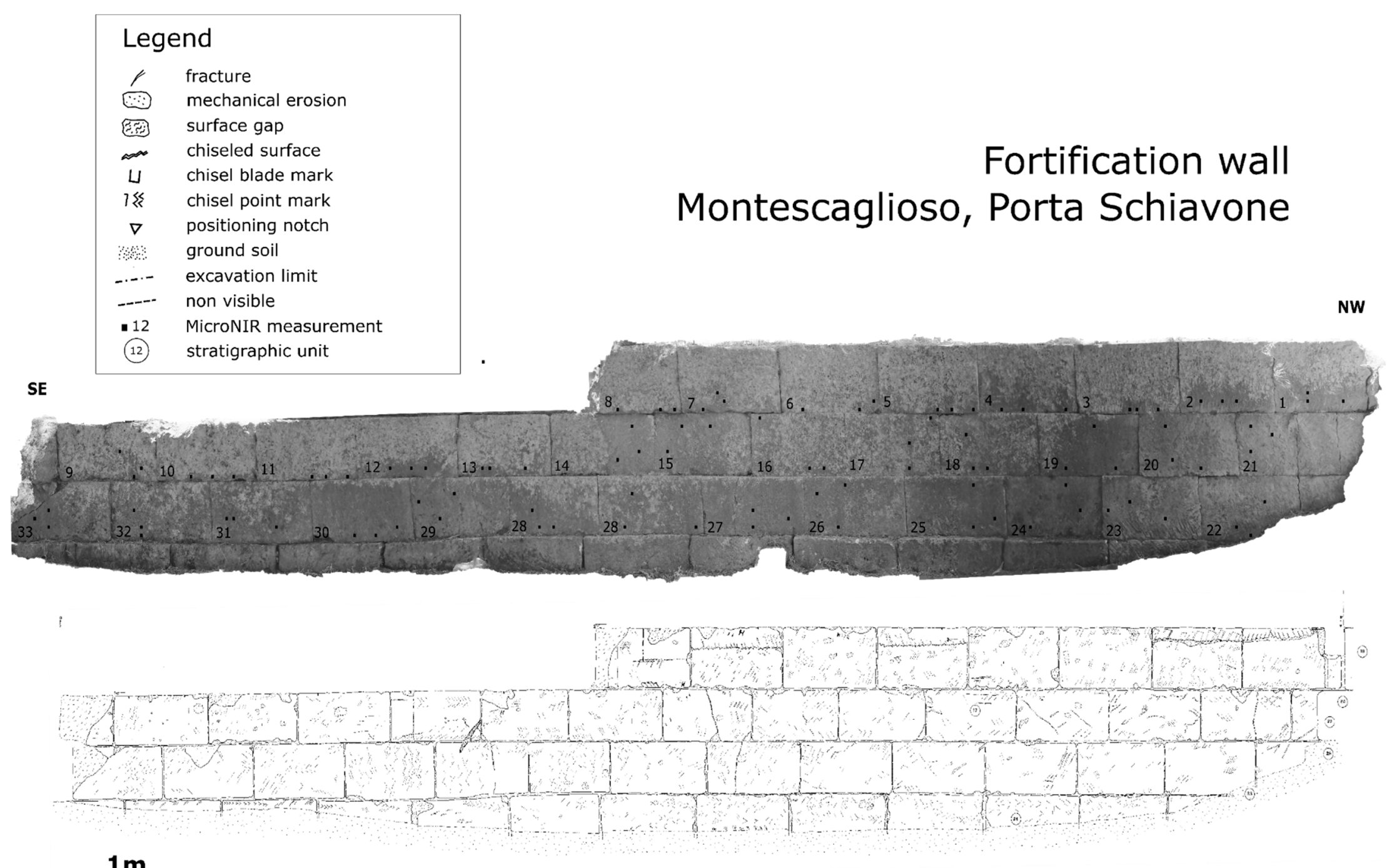

$1 \mathrm{~m}$

Figure 7. Documentation of one portion of the fortification wall at the site of Porta Schiavone, Montescaglioso [24]. 


\subsection{NIR Data}

The Micro NIR spectra collected on the various sites investigated were combined into two distinct datasets corresponding to the two campaigns (2015 and 2018). A PCA model was created for each dataset to reduce the spectral information and display distribution patterns (Figure 8a,b). The first model (Figure 8a) shows the results from the sites measured during the survey campaign in 2015. The spectra were mean centered and the Standard Normal Variate (SNV) correction was applied in order to reduce noise and highlight important spectral features. The score plot calculated for the first and second component shows overlapping clustering of the measurements collected at the quarry and on the coffins. In a cluster on the left corner, the measurements carried out on the oil press and the mortar found on the site of Difes San Biagio are grouped together. The loading line, on the right, displays the relevant peaks for the classification. In this case, the vibrations of $\mathrm{OH}$ molecules are in the first and third overtone.

The second model (Figure $8 \mathrm{~b}$ ) was calculated using the data collected during the second campaign, in 2018. The spectra were pre-processed in the same way, through a mean center and SNV correction. The PCA model, calculated for the first and third component, demonstrates that the clusters of measurements collected at the quarry and on the via Porta Schiavone fortification walls of Montescaglioso are overlapping, while the coffin analyzed from the same site does not match the same trend.
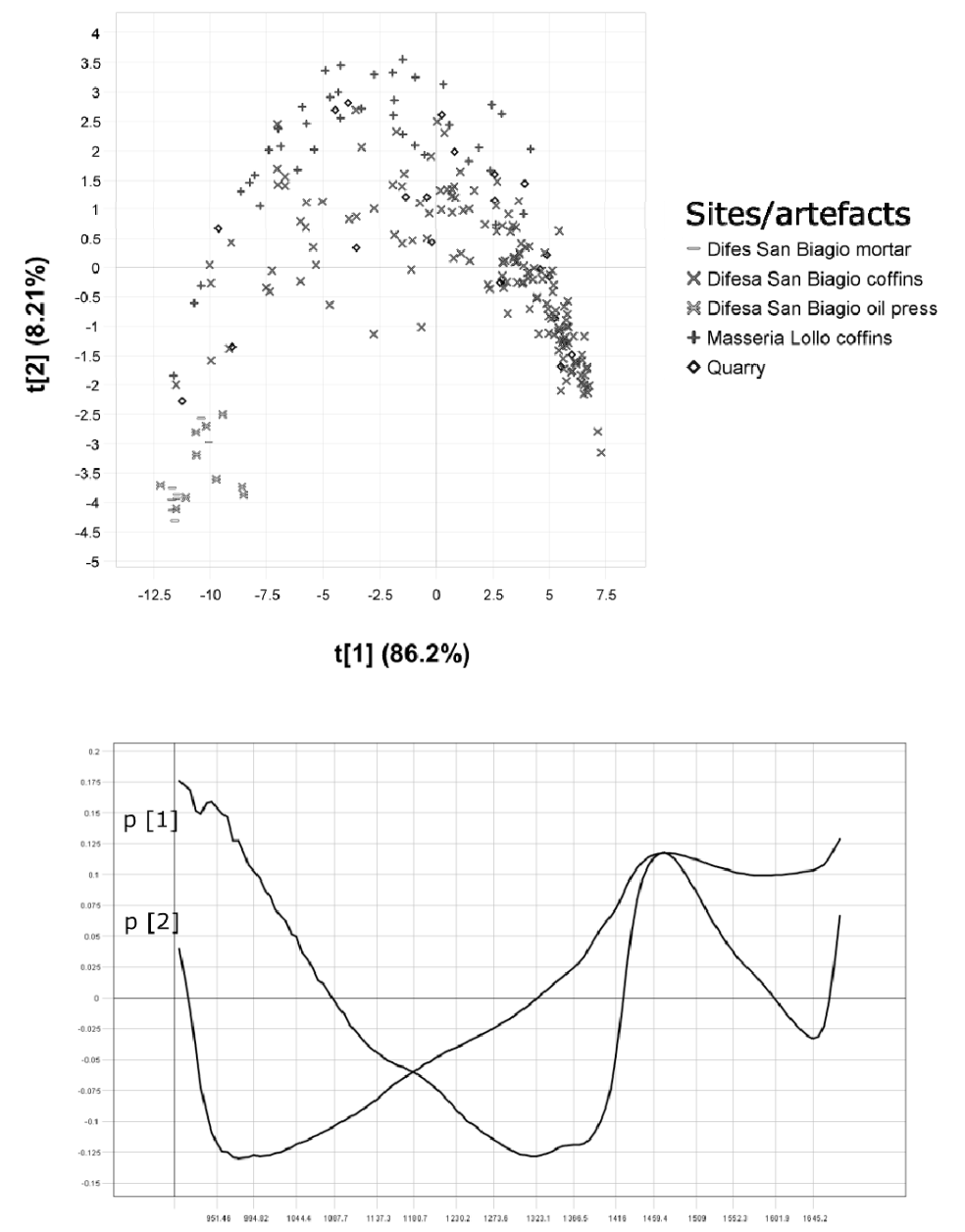

Line

(a)

Figure 8. Cont. 


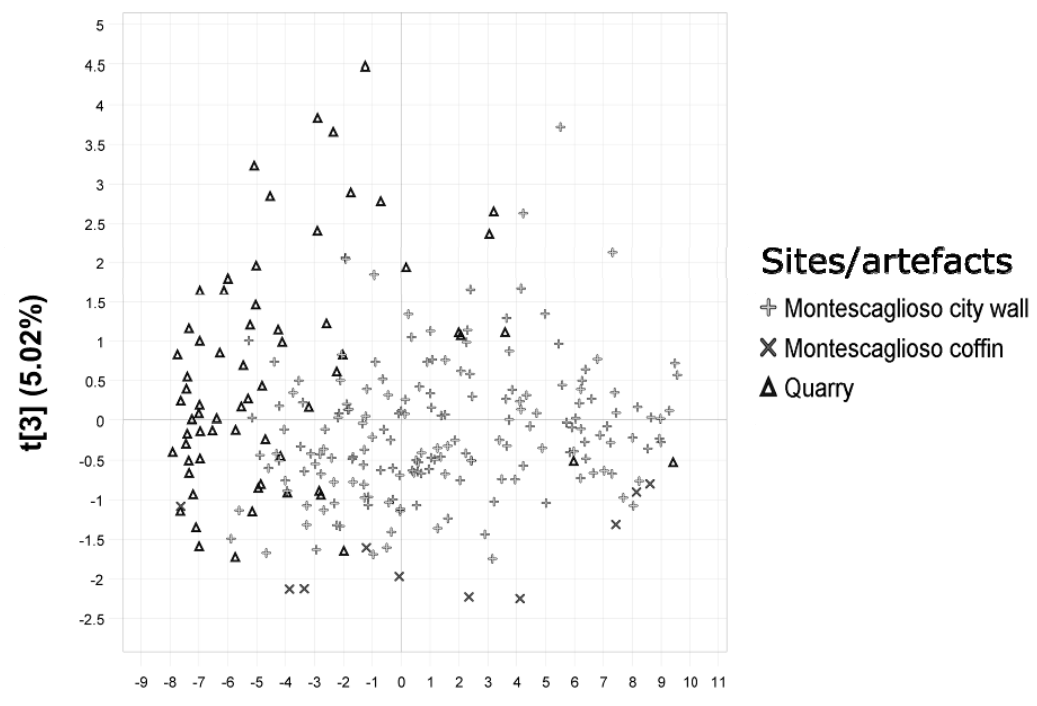

$t[1](86.8 \%)$

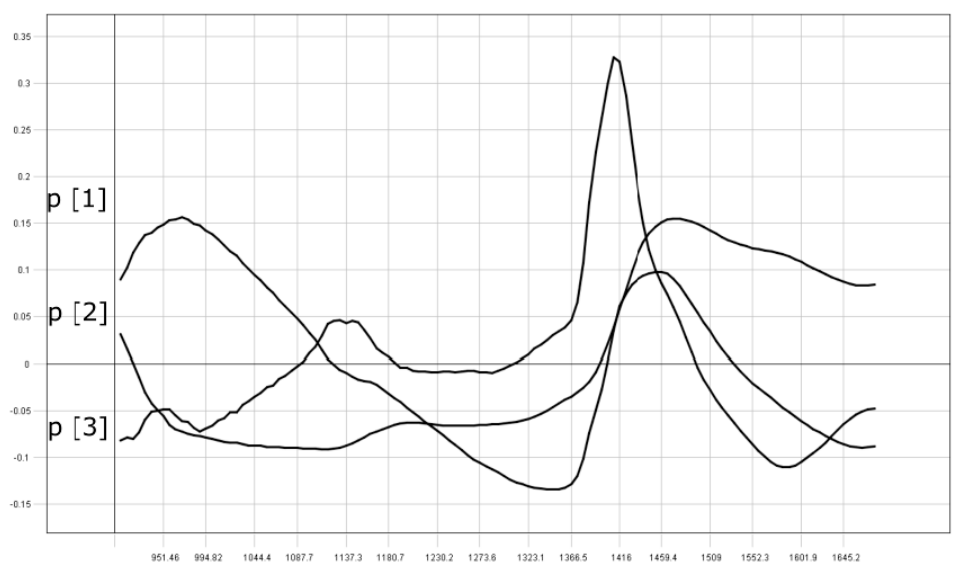

Line

(b)

Figure 8. (a) PCA models for the NIR measurements collected during the survey campaign in 2015. (b) PCA model for the NIR measurements collected during the survey campaign in 2018 [24].

The spectral characteristics of the calcareous rocks in the near infrared bands have been described by several authors who have highlighted how absorption peaks of the carbonates vary depending on the primary mineralogical composition of the stone types [53-56]. The distinctive infrared features of the carbonate rocks that characterize dolomite, aragonite, and calcite are particularly marked with peaks recorded at wavelengths higher than $1600 \mathrm{~nm}$. However, relevant absorption bands are characteristics of carbonate mineral, which can be found at lower bands. Together with peaks produced by $\mathrm{Fe}^{2+}$, the position and width of these features determine the spectral signature of the materials. The texture of particles also plays an important role in defining scattering effects. In the interval recorded by the instrument used for this study $(900-1700 \mathrm{~nm})$, the peaks relevant to the characterization of the materials are found around 1405/1416nm and $1450 \mathrm{~nm}$. 


\section{Discussion}

The spectral data collected provide a qualitative description of the geological characteristics of the rock. The fingerprint approach can help find trends and similarities among the deposits. Nevertheless, an accurate elemental or petrographic analysis is to be envisaged in order to confirm the preliminary matches.

In order to classify the collected dataset according to the most relevant spectral features, Soft Independent Modelling of Class Analogies (SIMCA) was applied. SIMCA is a classification model based on calculation of the critical distance (DmodX) [51,57]. The model permits the creation of a classification based on spectral difference deviating from a defined group of measures, which, in our case, is the quarry. When applying SIMCA for a selected class, a critical distance is calculated while the predicted data are plotted below or above it, according to their characteristics. This model is quite simple but effective in establishing the similarity or dissimilarity of two datasets. We performed a SIMCA model for each measured class associating it to the quarry in Masseria D'Alessio (Figure 9). According to this data-driven classification technique, both coffins at the sites in Difesa San Biagio and Masseria Lollo fall within the critical distance, which overlaps with the data collected at the quarry. Thus, we can formulate the hypothesis that the stone used for manufacturing the coffins was extracted from Masseria D'Alessio.

The same assumption can be made for the blocks used for constructing the defensive walls in Montescaglioso (via Porta Schiavone). Their spectral signatures match with those of the analyzed quarry.

Slightly different is the case of the coffin found near the walls in Montescaglioso. The calcarenite spectral fingerprint does not correspond to the quarry and its provenience is probably to be found elsewhere. Similar is the case of the mortar and millstone from the indigenous settlement of Difesa San Biagio. These calcarenite artifacts appear to be made of a raw material that does not match the outcrop in Masseria D'Alessio.

By integrating the documentation of tool marks with the preliminary classification of raw materials types, we can delineate the distribution of calcarenite artifacts, their provenance, and the production stages. The quarry analyzed in this study appears to have been specialized in the extraction of large modules, coffins, or masonry elements. The blocks were extracted using a pickaxe, which is a tool frequently used for working soft stones. A pickaxe was used for excavating the ditches while a chisel was probably handled to roughly evening out the surface of the blocks. The materials were then carried to the riverbank (where we could still observe some abandoned blocks) and loaded onto barges to be transported to the other sites. The slopes of Montescaglioso hill are not far from the extraction site and the settlement could be reached by sailing the Gravina-Fiumicello River and climbing up to the promontory. Once in place, if needed, stonecutters refined the blocks of stone, which were attached to the wall where the surfaces could have been uniformly dressed.

The sites of Masseria Lollo and Difesa San Biagio are situated further south. Nevertheless, the blocks could have been carried by partly sailing and then transporting them all the way up to the hills' ridges (Figure 1).

The considerable distance between the supply source and destination could be attributable to the geological characteristics of the region (as described in the first section of this paragraph). The calcarenite outcrop situated long the Gravina-Fiumicello stream's bank is the closest exploitable source of stone material. It is not clear if all the production phases of the coffins were completed at the quarrying site. We can assume that the large blocks were partially carved at the production site, without completing the details. The final polishing and eventual decoration of the surface could have been carried out at the settlements. This procedure would make the coffins lighter to transport (because they were partly carved) but thick enough to be resistant to the impact that could have occurred during transportation.

The screening analysis is also crucial to highlight that some of the artifacts included in this study did not match the quarrying site such as the coffin in Montescaglioso, as well as the oil press and 
mortar from Difesa San Biagio. We can hypothesise a different provenance for these artifacts, perhaps another workshop on a calcarenite outcrop located further north along the river.

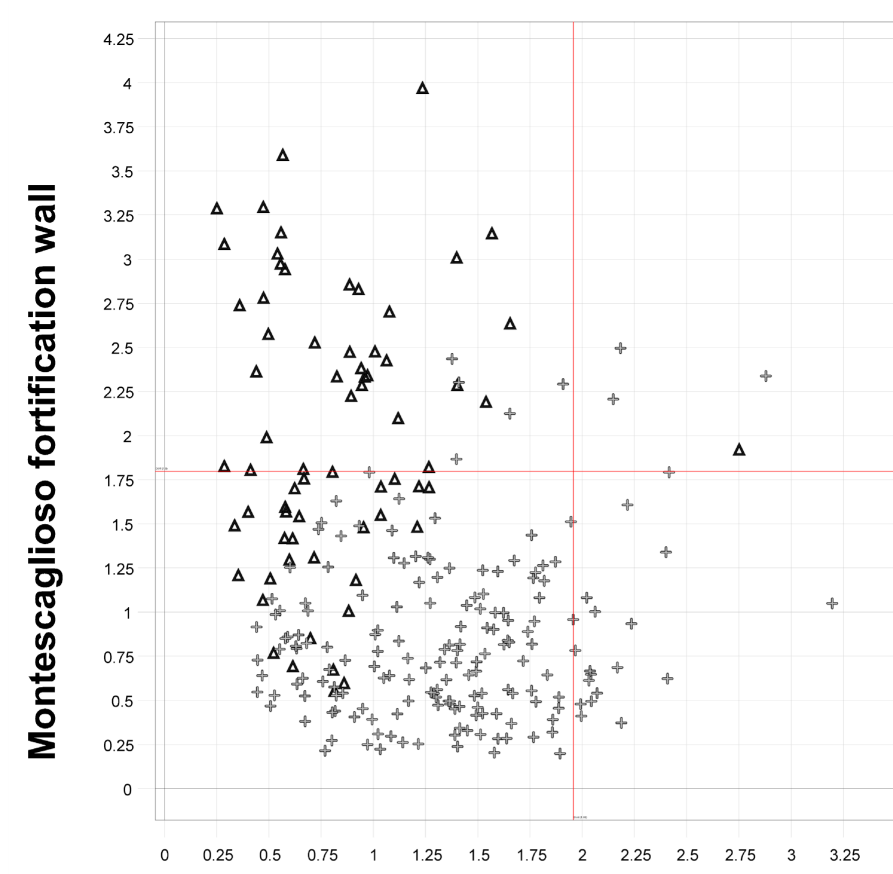

\section{Quarry}

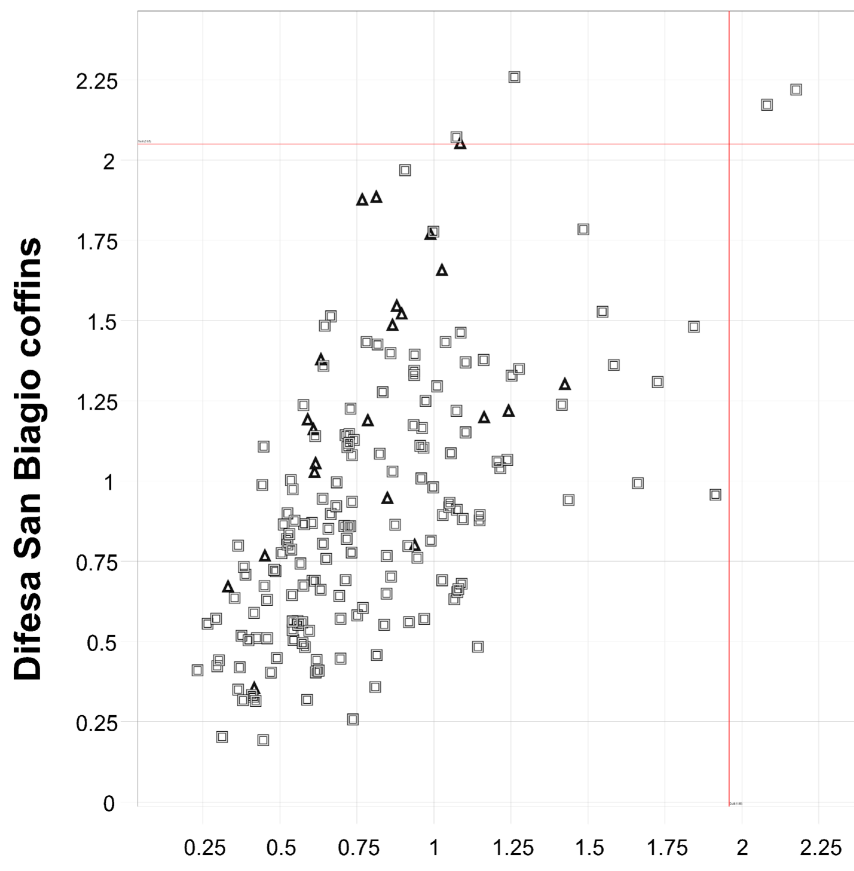

\section{Quarry}

Figure 9. Cont. 

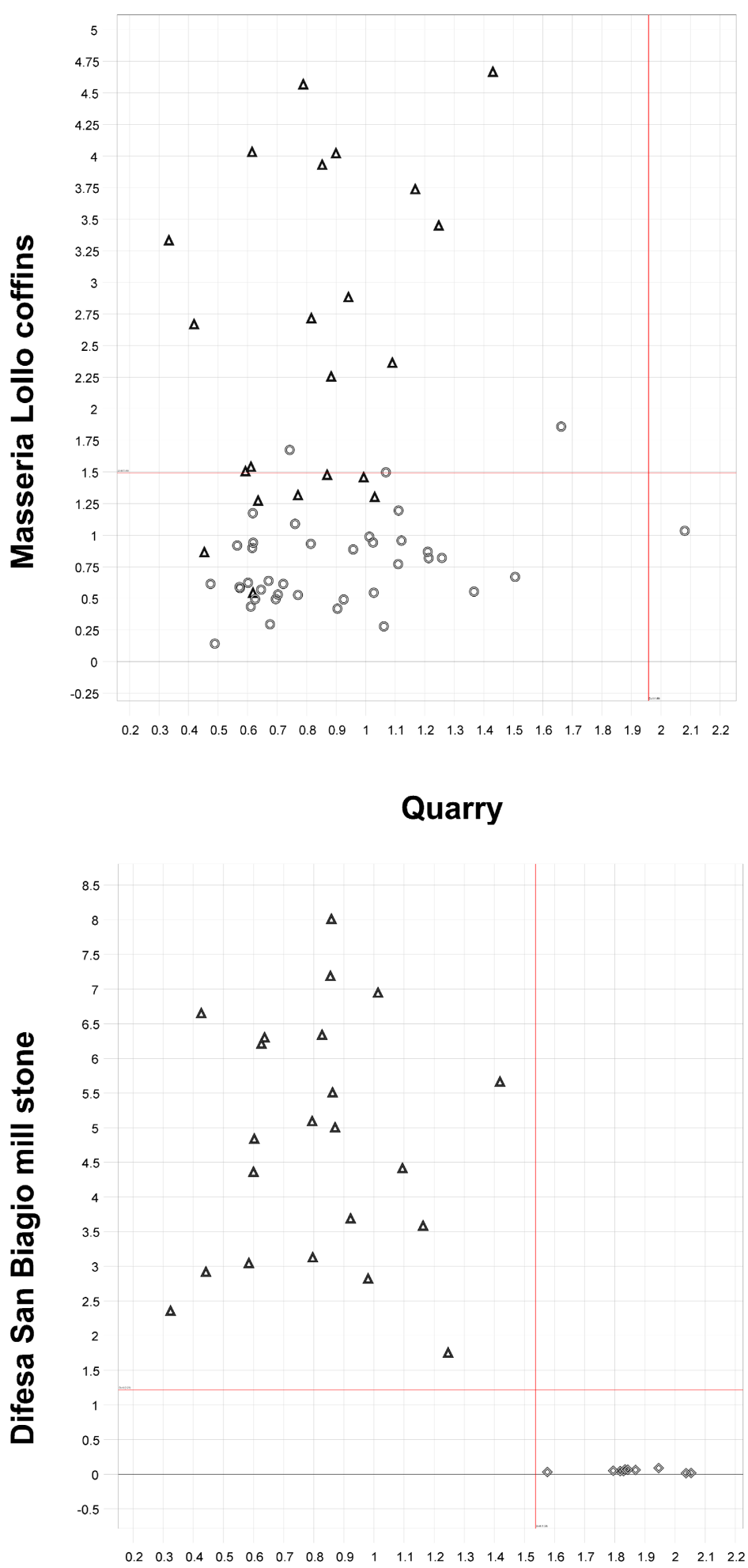

\section{Quarry}

Figure 9. Cont. 

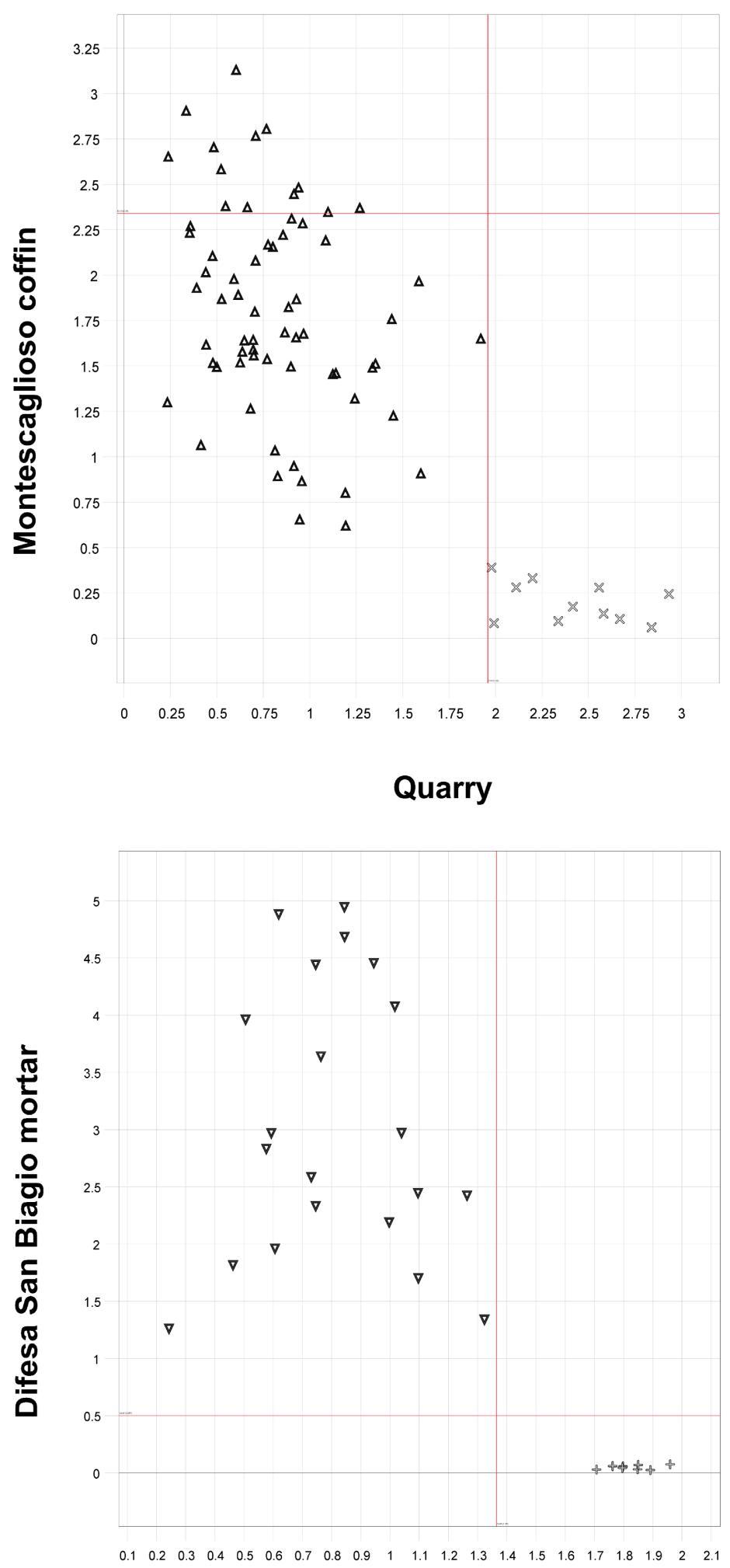

\section{Quarry}

Figure 9. SIMCA models for all the analyzed classes [24]. 


\section{Conclusions}

The method adopted for carrying out documentation of the stone artifact has proven effective for survey campaigns and has delivered useful knowledge about production and distribution of lithic products. With the support of digital tools, data collection was fast and efficient, gathering information about the geological characteristics of artifacts as well as their typology. The NIR hand-held probe is a versatile instrument that can be easily carried on a survey. The spectrometer is connected to a tablet used as a support for graphic documentation in conjunction with a digital camera. The protocol that was developed can be applied systematically to all types of stone materials identified and provides a database of combined geological and morphological information. The use of this kind of instrument can help with gathering information about the molecular features of rocks and can create clusters of similar stone types. Further analysis can also be carried out on the artifacts by planning the sampling strategy on a few items, according to the initial NIR results.

The poor conservation state of some of the artifacts found at the various sites represented an obstacle to the completion of the measurements. This issue unfortunately occurs in most circumstances collecting field measurements, where surface weathering could undermine the analytical results [58]. In this specific case, the use of the NIR probe was useful to collect measurements on the altered and unaltered portions of the rock surface, gathering a reference spectral dataset for lichens and weathered coatings, which could be compared to the measurements carried out on unaltered stone. Moreover, the collected dataset will serve as a reference for future measurements that will be performed to monitor the state of weathering of the artifacts.

The study conducted on the specific area around Montescaglioso demonstrated how the information collected with these tools could be crucial to shedding light on the production cycle of calcarenite objects, which highlights a network of workshops and exchanges and creating research questions for the future. The quarrying site located in Masseria D'Alessio appears to be dedicated to specific types of manufactured materials. The area was exploited over a prolonged period of time and most traces of old quarrying walls have been erased. Nevertheless, a detailed study of this site and its archaeological record could provide important information about the organization of labor over time and eventual changes in production planning. Knowing the origin and destination of the artifacts helps clarify the road access and means of transport. An accurate inquiry into the trails that were used between the quarry and the sites of Difesa San Biagio, Masseria Lollo, and Montescaglioso would be beneficial in elucidating modes of access and the passage of supply goods up the steep slopes. Lastly, the analysis of the spectral dataset gives a hint of the existence of the different production centers that supplied objects to the investigated sites, such as the oil press and mortar in Difesa San Biagio, together with the coffin in Montescaglioso. Further studies carried out using these techniques could be significant in delineating a larger panorama of the manufacturing process and the circulation of artifacts.

Author Contributions: D.R. planned and directed the survey and the landscape archaeology project. C.S. performed the analysis and processed the data. D.R. and C.S. wrote the manuscript together.

Funding: This research was partially funded by the Marcus and Amalia Wallenberg foundation, grant number MAW 2012.0136.

Acknowledgments: This project is part of the project CHORA. Laboratori di archeologia in Basilicata sponsored by the Graduate School in Archaeology of Matera-Unibas. Thanks to Valentino Vitale and Ester Annunziata for helping with the data acquisition. We wish to thank the anonymous reviewers for their comments that helped improving the text.

Conflicts of Interest: The authors declare no conflict of interest. The founding sponsors had no role in the design of the study; in the collection, analyses, or interpretation of data; in the writing of the manuscript, and in the decision to publish the results. 


\section{References}

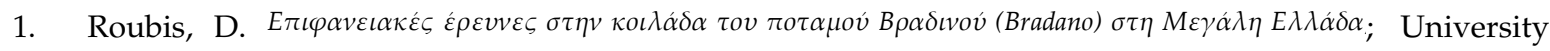
Studio Press: Thessaloniki, Greece, 2018.

2. Roubis, D.; Danese, M. Nuove metodologie per lo studio dei paesaggi storici della Basilicata: Le ricerche nella bassa valle del fiume Bradano. In Il Dialogo dei Saperi. Metodologie Integrate per i Beni Culturali; CNR Edizioni: Napoli, Italy, 2010; pp. 133-144.

3. Roubis, D.; Camia, F. $\triangle \mathrm{AZIMO} \Sigma$ XAIPE. Ricognizioni archeologiche e scoperte epigrafiche nel territorio di Montescaglioso: Nota preliminare. Siris 2011, 11, 111-122.

4. Roubis, D. Un progetto di Archeologia del Paesaggio in Basilicata. Il caso di studio di Montescaglioso. In Gli Allievi Raccontano; D’Andria, R., Mannino, K., Eds.; Congedo: Galatina, Italy, 2012; pp. 41-49, ISBN 9788880869627.

5. Roubis, D.; Colacino, C.; Fascetti, S.; Pascale, S.; Pastore, V.; Sdao, F.; De Venuto, G.; Florenzano, A.; Mercuri, A.M.; Miola, A. The archaeology of ancient pastoral sites in the territory of Montescaglioso (4th-1st century BC). An interdisciplinary approach from the Bradano valley (Basilicata-southern Italy). Siris 2013, 13, 117-136.

6. Giammatteo, T.; Roubis, D.; Pulice, I.; De Francesco, A.M.; Di Leo, P. Analisi mineralogiche dei manufatti provenienti dalle indagini archeologiche condotte nel territorio di Montescaglioso (MT): Problemi di approvvigionamento, produzione e tecniche di lavorazione. Siris 2013, 13, 137-150.

7. Mercuri, A.M.; Florenzano, A.; Massamba N'siala, I.; Olmi, L.; Roubis, D.; Sogliani, F. Pollen from archaeological layers and cultural landscape reconstruction: Case studies from the Bradano valley (Basilicata, southern Italy). Plant Biosyst. 2010, 4, 888-901. [CrossRef]

8. Edwards, H.G. Raman Spectroscopy at Longer Excitation Wavelengths Applied to the Forensic Analysis of Archaeological Specimens: A Novel Aspect of Forensic Geoscience. Infrared Raman Spectrosc. Forensic Sci. 2012, 481-511. [CrossRef]

9. Frahm, E. Validity of "off-the-shelf" handheld portable XRF for sourcing Near Eastern obsidian chip debris. J. Archaeol. Sci. 2013, 40, 1080-1092. [CrossRef]

10. Frahm, E.; Doonan, R.C. The technological versus methodological revolution of portable XRF in archaeology. J. Archaeol. Sci. 2013, 40, 1425-1434. [CrossRef]

11. Shackley, S.M. X-ray Fluorescense Spectometry (XRF) in Geoarchaeology; Springer: New York, NY, USA, 2012; ISBN 1-4614-3620-6.

12. Sciuto, C. Recording invisible proofs to compose stone narratives. Applications of Near Infrared Spectroscopy in provenance studies. Dig. Hum. Q. 2018, 12, 1-11.

13. Bottini, A. L'attività archeologica in Basilicata: 1993. In Proceedings of the Atti del XXXIII Convegno di Studi Sulla Magna Grecia, Taranto, Italy, 8-13 October 1993.

14. Bottini, A. L'attività archeologica in Basilicata: 1994. In Proceedings of the Atti del XXXIV Convegno di Studi Sulla Magna Grecia, Taranto, Italy, 7-11 October 1994.

15. D'Andria, F.; Roubis, D. L'insediamento indigeno di Difesa San Biagio a Montescaglioso. Seconda campagna di scavo. Syris 1999, 1, 123-155.

16. Roubis, D. Ricerche archeologiche nell'abitato indigeno di Difesa San Biagio (Montescaglioso). Ricerche sulla Casa in Magna Grecia e in Sicilia Atti del Colloquio Lecce 1996, 23, 234-253.

17. Roubis, D. The Leukania of Magna Graecia: Archaeological data from Basilicata (southern Italy). In Greek Colonization. New Data, Current Approaches, Proceedings of the Scientific Meeting, Thessaloniki, Greece, 6 February 2015; Alpha Bank: Athens, Greece, 2015; pp. 135-147.

18. Carter, J.C.; Prieto, A. The Chora of Metaponto 3: Archaeological Field Survey Bradano to Basento; University of Texas Press: Austin, TX, USA, 2011; Volume 3.

19. Castoldi, M. Oltre la Chora: Nuove Indagini Archeologiche Nell'Entroterra di Metaponto; Quaderni di Acme 102: Milano, Italy, 2008; ISBN 88-323-6200-7.

20. Di Leo, P.; Bavusi, M.; Corrado, G.; Danese, M.; Giammatteo, T.; Gioia, D.; Schiattarella, M. Ancient settlement dynamics and predictive archaeological models for the metapontum coastal area in basilicata, southern Italy: From Geomorphological survey to spatial analysis. J. Coast. Conserv. 2018, 22, 865-877. [CrossRef] 
21. Canosa, M.G. Montescaglioso. In Bibliografia Topografica della Colonizzazione Greca in Italia e nelle Isole Tirreniche; Nenci, G., Vallet, G., Eds.; Scuola Normale Superiore, Ecole Française de Rome: Rome, Italy, 1993; Volume 9, pp. 26-34.

22. Nava, M. L'attività della Soprintendenza archeologica della Basilicata nel 1997. In Proceedings of the Atti del XXXVII Convegno di studi sulla Magna Grecia, Taranto, Italy, 3-6 October 1997; pp. 872-905.

23. Nava, M. L'attività della Soprintendenza archeologica della Basilicata nel 1999. In Proceedings of the Atti del XXXIX Convegno di studi sulla Magna Grecia, Taranto, Italy, 1-5 October 1999; pp. 675-726.

24. Sciuto, C. Carved Mountains and Moving Stones: Applications of Near Infrared Spectroscopy for Mineral Characterisation in Provenance Studies; Umeå Universitet: Umeå, Sweden, 2018.

25. D'Ecclesiis, G.; Lorenzo, P. Frane relitte nei depositi della fossa bradanica: La frana di Madonna della Nuova (Montescaglioso, Basilicata). Giornale di Geologia Applicata 2006, 4, 257-262.

26. Pascale, S.; Pastore, V.; Sdao, F.; Sole, A.; Roubis, D.; Lorenzo, P. Use of remote sensing data for landslide change detection: Montescaglioso large landslide (Basilicata, southern Italy). Int. J. Agric. Environ. Inf. Syst. 2012, 3, 14-25. [CrossRef]

27. Boenzi, F.; Radina, B.; Ricchetti, G.; Valduga, A. Note Illustrative della Carta Geologica d' Italia alla Scala 1: 100000; Foglio 201: Rome, Italy, 1971.

28. Bessac, J.-C. L'outillage Traditionnel du Tailleur de Pierres de L'antiquité à nos Jours; Editions du Centre National de la Recherche Scientifique: Paris, France, 1986; ISBN 2-222-03607-0.

29. Bessac, J.-C. Traces d'outils sur la pierre: Problématique, méthodes d'études et interprétation. In Archeologia delle Attivitá Estrattive e Metallurgiche. V Ciclo di Lezioni sulla Ricerca Applicata in Archeologia (Certosa di Pontignano 1991); Francovich, R., Ed.; All' Insegna del Giglio: Firenze, Italy, 1993; pp. 143-176, ISBN 8878140325.

30. Bessac, J.-C.; Sablayrolles, R. Problématique archéologique des carrières antiques en Gaule. Gallia 2002, 59, 3-9. [CrossRef]

31. Rockwell, P. The Art of Stoneworking: A Reference Guide; Cambridge University Press: Cambridge, UK, 1993; ISBN 0-521-41332-X.

32. Roubis, D.; Aino, L. Cugno La Volta-San Nicola: Un luogo di culto nelle vicinanze del sito di Difesa San Biagio (Montescaglioso-MT). Siris 2013, 13, 151-182.

33. De Siena, A.; Di Tursi, A.; Trivigno, L.; Lapadula, E.; Patrone, A.; Giannichedda, E. Scavi archeologici nell'area dell'abbazia di San Michele Arcangelo a Montescaglioso (MT). Archeol. Postmed. 2007, 11, 1000-1028.

34. Goffer, Z. Archaeological Chemistry; John Wiley \& Sons: Hoboken, USA, 2006; Volume 170, ISBN 0-471-91515-7.

35. Price, T.D.; Burton, J.H. An Introduction to Archaeological Chemistry; Springer Science \& Business Media: New York, NY, USA, 2010; ISBN 1-4419-6376-6.

36. Pollard, A.M.; Heron, C. Archaeological Chemistry; Royal Society of Chemistry: Cambridge, MA, USA, 2015; ISBN 1-78262-611-5.

37. Goetz, A.F.; Rock, B.N.; Rowan, L.C. Remote sensing for exploration: An overview. Econ. Geol. 1983, 78, 573-590. [CrossRef]

38. Greenberger, R.N.; Mustard, J.F.; Ehlmann, B.L.; Blaney, D.L.; Cloutis, E.A.; Wilson, J.H.; Green, R.O.; Fraeman, A.A. Imaging spectroscopy of geological samples and outcrops: Novel insights from microns to meters. GSA Today 2015, 25, 4-10. [CrossRef]

39. Gupta, R.P. Remote Sensing Geology; Springer Science \& Business Media: New York, NY, USA, 2013; ISBN 3-662-05283-0.

40. Kruse, F.A. Mapping surface mineralogy using imaging spectrometry. Geomorphology 2012, 137, 41-56. [CrossRef]

41. Cavalli, R.M.; Colosi, F.; Palombo, A.; Pignatti, S.; Poscolieri, M. Remote hyperspectral imagery as a support to archaeological prospection. J. Cult. Herit. 2007, 8, 272-283. [CrossRef]

42. Parcak, S.H. Satellite Remote Sensing for Archaeology; Routledge: London, UK, 2009; ISBN 1-134-06045-9.

43. Marini, F.; Tomassetti, M.; Piacentini, M.; Campanella, L.; Flamini, P. Application of near infrared spectroscopy (NIR), X-ray fluorescence (XRF) and chemometrics to the differentiation of marmora samples from the Mediterranean basin. Nat. Prod. Res. 2016, 7, 1-9. [CrossRef] [PubMed]

44. Sciuto, C.; Linderholm, J.; Geladi, P. Near Infrared Imaging Spectroscopy for Raw Materials Characterization: The Example of a Mesolithic Dwelling Site in Northern Sweden. In The Exploitation of Raw Materials in 
Prehistory: Sourcing, Processing and Distribution; Pereira, T., Terradas, X., Bicho, N., Eds.; Cambridge Scholars Publishing: Newcastle upon Tyne, UK, 2017.

45. Linderholm, J.; Geladi, P.; Sciuto, C. Field-based near infrared spectroscopy for analysis of Scandinavian Stone Age rock paintings. J. Infrared Spectrosc. 2015, 23, 227-236. [CrossRef]

46. Sciuto, C.; Geladi, P.; La Rosa, L.; Linderholm, J.; Thyrel, M. Hyperspectral Imaging for Characterization of Lithic Raw Materials: The Case of a Mesolithic Dwelling in Northern Sweden. Lithic Technol. 2018, 1-14. [CrossRef]

47. Sciuto, C.; Allios, D.; Bendoula, R.; Cocoual, A.; Gardel, M.-E.; Geladi, P.; Gobrecht, A.; Gorretta, N.; Guermeur, N.; Jay, S. Characterization of building materials by means of spectral remote sensing: The example of Carcassonne's defensive wall (Aude, France). J. Archaeol. Sci. Rep. 2019, 23, 396-405. [CrossRef]

48. Parish, R.M. The application of visible/near-infrared reflectance (VNIR) spectroscopy to chert: A case study from the Dover Quarry sites, Tennessee. Geoarchaeology 2011, 26, 420-439. [CrossRef]

49. Rinnan, Å.; van den Berg, F.; Engelsen, S.B. Review of the most common pre-processing techniques for near-infrared spectra. TrAC Trends Anal. Chem. 2009, 28, 1201-1222. [CrossRef]

50. Wold, S.; Albano, C.; Dunn, W.J.; Edlund, U.; Esbensen, K.; Geladi, P.; Hellberg, S.; Johansson, E.; Lindberg, W.; Sjöström, M. Multivariate data analysis in chemistry. In Chemometrics; Springer: New York, NY, USA, 1984; pp. 17-95.

51. Eriksson, L.; Byrne, T.; Johansson, E.; Trygg, J.; Vikström, C. Multi- and Megavariate Data Analysis Basic Principles and Applications; Umetrics Academy: Umeå, Sweden, 2013; ISBN 91-973730-5-2.

52. Koehler, F.W.; Lee, E.; Kidder, L.H.; Lewis, E.N. Near infrared spectroscopy: The practical chemical imaging solution. Spectrosc. Eur. 2002, 14, 12-19.

53. Crowley, J.K. Visible and near-infrared spectra of carbonate rocks: Reflectance variations related to petrographic texture and impurities. J. Geophys. Res. Solid Earth 1986, 91, 5001-5012. [CrossRef]

54. Gaffey, S.J. Spectral reflectance of carbonate minerals in the visible and near infrared $(0.35-2.55 \mu \mathrm{m})$ : Anhydrous carbonate minerals. J. Geophys. Res. Solid Earth 1987, 92, 1429-1440. [CrossRef]

55. Gunasekaran, S.; Anbalagan, G.; Pandi, S. Raman and infrared spectra of carbonates of calcite structure. J. Raman Spectrosc. 2006, 37, 892-899. [CrossRef]

56. Hunt, G.R.; Salisbury, J.W. Visible and near infrared spectra of minerals and rocks. II. Carbonates. Mod. Geol. 1971, 2, 23-30.

57. Brereton, R.G.; Jansen, J.; Lopes, J.; Marini, F.; Pomerantsev, A.; Rodionova, O.; Roger, J.M.; Walczak, B.; Tauler, R. Chemometrics in analytical chemistry-Part II: Modeling, validation, and applications. Anal. Bioanal. Chem. 2018, 410, 6691-6704. [CrossRef] [PubMed]

58. Winkler, E. Stone in Architecture: Properties, Durability; Springer Science \& Business Media: New York, NY, USA, 2013; ISBN 3-662-10070-3.

(C) 2019 by the authors. Licensee MDPI, Basel, Switzerland. This article is an open access article distributed under the terms and conditions of the Creative Commons Attribution (CC BY) license (http:/ / creativecommons.org/licenses/by/4.0/). 